\title{
Mexican water studies in the Mexico-US borderlands
}

\author{
Casey Walsh ${ }^{1}$ \\ University of California, Santa Barbara, USA \\ "Something there is that doesn’t love a wall"
}

- Robert Frost

Robert Frost's poem "Mending Wall" captures the contradictory character of our relationships to borders. In the US, common understandings of the Mexico-US border see it as necessary to keep out intruders and establish a barrier between nations, races and social classes. In Mexico some of these same ideas exist, usually expressed in a more critical tone born of an understanding of the asymmetry of power relations between the two countries. The Mexico-US border is a formidable barrier, but people, things and ideas do move across it with lesser or greater ease; water in rivers and aquifers moves across borders because it flows downhill, regardless of the political boundaries of states. Human movements are mediated by kinship, community, state bureaucracy and a host of affective dimensions, often quite positive. In fact, these movements are often spurred by the existence of the border, as people seek advantages on one side or the other. The ceaseless process of crossing borders gives pause to reflect on their constructedness, their functions, and, as Frost put it, what we don't love about them.

The essays grouped together in this special section of the Journal of Political Ecology present a Mexican perspective on water in the Mexico-U.S. borderlands. To insure coherence among the articles, the authors were asked to discuss the transnational dimensions of water use and management in the borderlands. The project to collect and present articles of leading Mexican scholars of water in English had its origin in the dissatisfaction of this author with the failure of many Mexican and US scholars studying water to really engage in discussion across the national divide. Of course, there are some who have made this crossing (Evans, forthcoming; Melville and Whiteford 2002; Sanchez Munguia 2005), but scholars of the US West and water historians in particular (for example, Worster 1985; Pisani 1984, 2002) often ignored the long and important trajectory of Mexican anthropology and history of water (reviewed briefly below), and the existence of strong research on the topic in the northern Mexican borderlands. That scholars on both sides of the national divide shared major research themes and theoretical questions - aridity, hydraulic infrastructure, water law, state formation, capitalism - made this disjuncture even more perplexing. Translating and publishing Mexican water scholars in an open-source journal in English looked like a promising step across the wall that separates academic production in Mexico and the United States.

Like many other dimensions of life in the borderlands, the scholarship in the pages of this special section of the Journal of Political Ecology is at the same time oriented by, yet transgressive of, the national-state divide and the ways it has shaped the dynamics of the social use of water in the region, as well as the intellectual effort to understand these dynamics. Water has long been an exceptionally creative and fertile field of study in Mexican history and anthropology, but this scholarship remains largely unknown outside of the country, even among scholars of water in the United States who focus on the binational border region. The particular anthropological and historical current of water research I am discussing here is not the only one in Mexico, of course, and so this Introduction and the articles that follow in this section do not represent all the scholarship on the topic in Mexico. Nevertheless, in what follows I will situate these three articles within this rich intellectual tradition, stressing its "borderlands" character: transnational but still very Mexican. I will then turn to the topic of borderlands water itself by briefly presenting the content of each article and their shared themes.

Karl Wittfogel is the usual starting place for discussions of water in history and anthropology. He was a scholar of Asian civilizations who was involved in the Frankfurt school of critical Marxism in the 1920s, and who shared with that school a deep interest in the role of the state in revolutionary change. Wittfogel used the research of archaeologists working in Asia and the Middle East to construct a theory of state formation that linked bureaucratic power to the construction of hydraulic works in arid and semi-arid areas. Although his most extensive

1 Dr. Casey Walsh, Associate Professor, Department of Anthropology, University of California, Santa Barbara, Santa Barbara, CA 93106-3210, USA. Email: walsh "at" anth.ucsb.edu. The author is particularly indebted to John Donahue, Irene Klaver and the rest of the collaborators in the "Neighborly Waters" project, who helped refine many of the ideas presented here. All errors and inaccuracies are my own, of course. This article is part of a Special Section on "Mexican water studies in the Mexico-US borderlands," edited by Casey Walsh. 
treatment of the topic, Oriental Despotism appeared in 1957, he was publishing about water and the state since 1938 (Wittfogel 1938). Drawing on the insights of Max Weber and Karl Marx, Wittfogel argued that the construction and management of hydraulic works of irrigation and flood control required the centralized control of a class of managers to organize the labor of those who built and repaired the works, and that this effort to control water reproduced the power of those rulers (Wittfogel 1957). The immense importance of the state in the economy in ancient Egypt, China, Mesopotamia and other ancient complex societies led Wittfogel to follow Marx in identifying a distinct "Asiatic" mode of production, quite different from the capitalist mode that emerged in "the west." Wittfogel's ideas about despotism and totalitarianism must be seen as a reaction to the context of fascism, nazism and stalinism in which he was engulfed, and this context led him to exaggerate his conclusions about the total power of the state that builds hydraulic works. ${ }^{2}$ Wittfogel's concept of "oriental despotism" has largely been rejected as a result of sustained and profound criticism, but has nevertheless had an enduring impact on anthropology and history in the United States and in Mexico. Julian Steward's 1955 edited volume on Irrigation Civilization, which included chapters by Karl Wittfogel and Mexican anthropologist Angel Palerm, is often seen as a reflection of this impact in its founding moment (Steward 1955). However, as the presence of Palerm and others in that volume indicates, Wittfogel was only one among many influences that shaped the history of research on water and power in Mexico and the U.S.

In the U.S., Steward's cultural ecology approach was a parallel and previous development that sought links between the material, productive relationships established by humans with their environment, and the social and cultural aspects of human life (Steward 1949). Steward was a great synthetic thinker, interested in comparisons and causes, and his focus on human-environment relations led him to address the kinds of issues about the evolution of social complexity that Wittfogel was interested in. His classic 1949 article-statement, Cultural causality and law: a trial formulation of the development of early civilizations, was explicit about the importance of water in his research and theory, for he consciously limited his evidence to civilizations in arid and semi-arid regions that utilized irrigation (Steward 1949). This perspective was very influential in the mid-twentieth century, is the direct ancestor of political economy and political ecology approaches in social and cultural anthropology (Roseberry 1978; Greenberg and Park 1994), and had clear impacts in others disciplines, including geography. According to Sidney Mintz, however, Steward's cultural ecology of complex society, and his interest in irrigation and water, was rooted in his early work $(1930 ; 1933)$ on the Shoshone Paiute of the interior deserts of California, where he described irrigation techniques in the absence of intensive agriculture (Mintz 1979). This research was carried out almost two decades before he engaged Wittfogel in the discussion of the origins of the hydraulic state, and thus constitutes an independent intellectual trajectory.

Cultural Causality, and Steward's cultural ecology approach in general, resonated strongly among Mexican anthropologists who were already working on issues of water management and social evolution. Angel Palerm, a Republican militant in the Spanish civil war, emigrated from Spain to Mexico during the war and entered into the B.A. program at the National School of Anthropology, housed at the Instituto Politecnico (the ENA, for its initials in Spanish; now known as the ENAH). The ENAH had been founded a few years earlier, and its first teachers included Paul Kirchhoff, an exiled German communist steeped in European marxism, and Pedro Armillas, who was influenced by Kirchhoff's historical materialism. During the 1940s Armillas worked for the National Museum of Mexico setting up exhibits on water management and social evolution in Mesoamerica, and published a "landmark" paper in 1949 that argued for the importance of irrigation and "previously unseen relationships among agricultural system, climate, population density, and location of urban centers at the time of the Conquest" (Freeman 1986).

Armillas directed Palerm's 1951 BA thesis at the ENAH on irrigation and urbanization in ancient Mexico. In 1952 Angel Palerm took a job in the Department of Cultural Affairs of the Pan American Union in Washington D.C., and quickly got involved in the international discussion of irrigation and state formation. In 1953 he organized a symposium on the topic of Irrigation Civilizations, which led to the publication of Irrigation Civilizations. Palerm published a series of articles in the 1950s on this topic (Palerm 1952; 1954; 1955), and established dialogues with Wittfogel, Steward and Steward's students, Eric Wolf and Sidney Mintz. Wolf and Palerm began their lifelong friendship and intellectual collaboration with publications on irrigation in the Texcoco area of the Valley of Mexico (Palerm and Wolf 1954; 1957). Wittfogel's work on oriental despotism and the "Asiatic mode of production" was of interest to Palerm because he was already grappling with similar issues in Mexico (González 2007). Although Wittfogel’s influence on Palerm is undeniable, Palerm had a more multilineal and anthropological perspective than Wittfogel; a perspective that can be traced to his intellectual formation at the ENAH, and his discussions with Steward and his students.

Angel Palerm returned to Mexico in the 1960s, and after struggling to gain a foothold in the academic and research institutions of the Mexican state, found a home at the Universidad Iberoamericana (UIA), a private Jesuit university. He soon became an intellectual giant, who collaborated with Gonzalo Aguirre Beltrán and other pillars

2 For a more complete discussion of Wittfogel's theory of hydraulic societies and oriental despotism, see Krader (1975) and Llobera (1980). 
of modern Mexican anthropology, and trained generations of students at the UIA. He was a builder who created some of the most important anthropological institutions in the country, including the Graduate Program in Social Anthropology at the Universidad Iberoamericana (UIA), and the Centro de Investigacion y Estudios Superiores en Antropología Social (CIESAS). His students filled positions at these institutions and others, including the Anthropology Department at the Universidad Autonoma Metropolitana in Iztapalapa (UAM-I), and the program in Rural Sociology at the Colegio de Posgraduados (Colpos). In the later part of his career Palerm concentrated on Marxist approaches to anthropology (Palerm 1980), and wrote a universal history of the discipline as seen from Mexico. However, his students continued to work on issues surrounding environment, society and power, and many of them focused on water.

The three authors who contribute to this special section of the Journal of Political Ecology are all heirs to the institutional legacy and research tradition of Angel Palerm, to different extents, and in different ways (Figure 1). Tomás Martínez Saldaña, a native of the northern Mexican agricultural zone known as the Laguna, took his BA, $\mathrm{MA}$ and $\mathrm{PhD}$ with Angel Palerm at the Iberoamericana, before joining the Rural Sociology department at the Postgraduate College of the National Agricultural School (the Colegio de Posgraduados). Martínez's research on northern Mexico and the Southwest United States has always taken place in the context of irrigation: first large systems such as that of the Laguna region (Martínez Saldaña 1980), and later smaller irrigation systems (Martínez Saldaña and Palerm Viquiera 1997). In both large and small systems, Martínez inquires about the role of water, and water infrastructure, in the formation of the state.

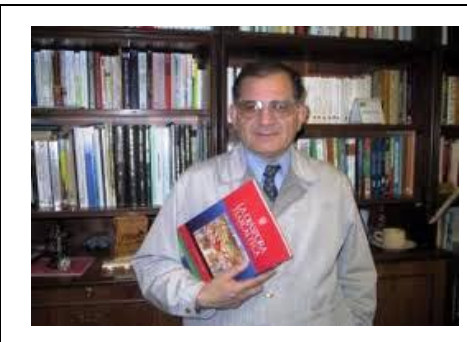

Tomás Martínez Saldaña

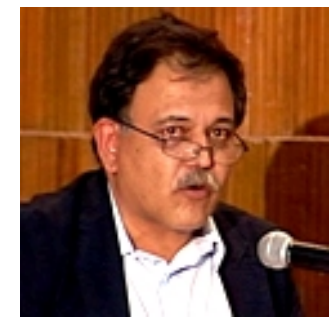

Luis Aguilar Aboites

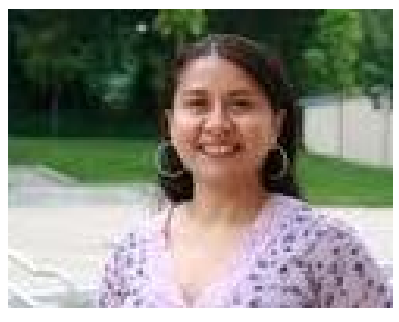

Carmen Maganda

Figure 1. Authors in this Special Section. Source: University websites.

Like much of Mexican social anthropology, this research engages with the large issues of the period: in this case, the neoliberal decentralization of water management and other state functions since the early 1980s. Palerm and his students critiqued the domination by the Mexican state of peasants and other rural producers, and the negative consequences of national politics as applied in rural Mexico (Martínez Saldaña 1980; Palerm 1980; Warman 1975). Anthropologists interested in small irrigation systems in Mexico and the Southwest United States have generated a considerable number of case studies that show the dynamics of the local organization of water (Martínez Saldaña and Palerm Viquera 1997; Rodríguez 2006; Rivera 1998). Research on pequeño riego underscores the idea that while these systems do not necessarily lead to the formation of states, issues of centralization and power are present in all scales of water management, including the smallest (Donahue and Johnston 1998; Melville and Whiteford 2002).

In the article published here, Martínez Saldaña presents research on the long history of what is today northern Mexico and the Southwest United States, to recover millennial traditions of Mesoamerican water culture that still shape the use of the resource throughout the binational region, despite a profound reshaping of environment and society by state-led modernist hydraulic projects during the twentieth century (Martínez Saldaña 2012). He notes how very little we know about the diversity of uses made of the water of the Río Bravo/Rio Grande, one of the largest and most conflict-ridden river basins in the hemisphere. In the sixteenth and seventeenth centuries, as the colonial government expanded into western and northern Mexico in search of silver, the creoles and mestizos of central Mexico enlisted their Tlaxcaltecan Indian allies as soldiers and colonists. Tlaxcaltecans carried with them to these arid zones their technology and infrastructure, their cultural understandings of the value of water, their religious rituals and celebrations, and even their Mesoamerican food crops. This borderlands agroecological and cultural tradition has survived, often hidden, and constitutes an inheritance for humanity that provides a model for sustainable long-term water management at a time when water scarcity in the borderlands is reaching a state of crisis.

Luis Aboites takes up the story of water use in the borderlands of northern Mexico during the late-nineteenth and twentieth centuries, when advances in engineering, technology and agricultural production completely 
reworked human relationships to water and the environment, superceding and destroying many of the earlier, smaller water systems and societies in the region discussed by Martínez Saldaña (Aboites 2012). Aboites is a native of the northern irrigated agricultural zone of Delicias, Chihuahua, and was in the first generation trained in the BA program of the Anthropology Department of the UAM Iztapalapa, a program founded by students of Angel Palerm in the early 1970s. Despite this training, his work is not explicitly engaged with anthropological theory. His first book, La Irrigacion Revolucionaria (Aboites 1988) was a pathbreaking history of state formation and irrigation agriculture in Chihuahua. The central argument of the book - that the bourgeois state built its power after the revolution on irrigation works and industrial agriculture in the borderlands - was clearly influenced by the anthropological tradition of multilineal social evolution advanced by Armillas and Palerm, but is fundamentally historical in its methods and data. Later works continued to develop these ideas about the importance of water in the creation of society in northern Mexico, and the ascendency of the postrevolutionary state associated with water control (Aboites 1995; 1998). He was instrumental in the creation of the National Water Archives in Mexico (Archivo Historico del Agua), and is now professor of history at the Colegio de México. Although he has done an enormous amount of work on water, it focuses on economics and politics more than the environment. Later research continues in this trajectory, focusing on taxation and the postrevolutionary state.

In this article Aboites explores the history of hydraulic engineering in the Mexican borderlands, lodging this story within a larger narrative of water control and the formation of the postrevolutionary state. The construction of irrigation infrastructures in northern Mexico was, Aboites points out, a thoroughly transnational process that involved businesses, engineers, ideas and technologies from France and United States. He provides an historical overview of Mexican irrigation efforts in the areas bordering the United States, and discusses how late-nineteenth and early-twentieth century liberal economic ideologies defined modernization in terms of the breakup of the large landholdings, the construction of large-scale irrigation projects, and the creation of a small-farmer class. He notes that North American influence in the process included contracts with American engineering firms, imported construction equipment, and eventually the rise of American-financed farms that produced cotton for domestic consumption and export. Paralleling these foreign influences, Aboites notes the gradual "Mexicanization" of engineering expertise and geopolitical strategies that would underlie Mexican contributions to the 1944 Water Treaty between that country and the United States. As a result, an agricultural regime of accumulation was erected that was remarkably unified on both sides of the border. This transnational historiographical perspective is an important corrective to the nationalist tendencies of some histories of northern Mexico. It builds on the Mexican tradition of water research, but it pushes us to rethink the territorial boundedness of state formation, and to recover the importance of the economy in that process, an insight that Palerm, Steward and Wittfogel all shared, but which is not often remembered by those working in cultural ecology and political ecology.

The political and cultural dimensions of water management in the borderlands mentioned by Aboites are the focus of the article by Carmen Maganda (Maganda 2012). Maganda received her PhD at the CIESAS, in Mexico City, under the tutelage of Roberto Melville, a former student of Angel Palerm at the Iberoamericana, and now a leader in water scholarship who, working in the graduate program at the CIESAS, has trained a number of anthropologists working on that topic. Melville's own PhD research focused on the social and political dimensions of the Tennessee Valley Authority, a paragon of "high modernist" (Scott 1998) hydraulic state formation, and he has traced the influence of the TVA model of development in Mexico in river-basin development schemes such as the Papaloapan project (Melville 1993). Maganda wrote her PhD about aquifers and water politics in the Bajio region of Guanajuato. She has continued to develop the political side of her work, incorporating literature from sociology and political science, and focusing on comparative border studies.

Maganda has made the cross-border perspective central to her research, and has pushed Mexican anthropology of water to include more political and cultural theory. The 1944 Treaty between Mexico and the United States remains the defining legal institution governing water between the two countries, and it subsumes and is accompanied by a myriad of national, interstate, state and local level laws, especially in the U.S. where state and local law are relatively more important than they are in Mexico. Since the 1980s, and particularly with the passage of NAFTA, other regulatory frameworks and institutions have been created to deal with cross-border environmental issues. These new legal and political infrastructures confront, on the one hand, globalization and regionalization, and, on the other, ecological crisis. In Maganda's work, the relationship between water control and state formation - the marrow of the Mexican tradition of water studies - takes the form of laws, government institutions, and political culture.

In her chapter, Carmen Maganda shows the importance of culture to water politics in the binational Colorado River watershed, and also how borderlands political culture has shifted over time. She sees two cultural dimensions at play in current border water management. The first is political culture based on community norms that promotes local and even cross-border cooperation in water distribution. The second is a more institutionallybased political culture reflecting an ethic of efficiency and a calculative style that rewards strategic planning in water management at the municipal, regional, national and even international levels. By bridging disciplines in her analysis, she shows that border water scholars fail to unite their analysis of these two realms - if they mention culture at all. She notes that the dominance of the institutional culture in the field of border water politics may limit the possibilities of cooperation within civil society at the local level. The failure of the bi-national water treaties to 
include sharing of groundwater or the quality of shared surface water further aggravates the tension between the two approaches. Maganda demonstrates how the two cultural strategies play themselves out in the case of the AllAmerican Canal, which was recently lined with cement in order to prevent seepage and increase water supplies to San Diego and Los Angeles, and in doing so effectively took the liquid away from farmers in the Mexicali Valley.

The relations between humans and water in the Mexico-US borderlands are increasingly strained. The borderlands economy has evolved through a series of dominant activities including mining and ranching, intensive agriculture, industry and services. Spurred by these activities, especially industry and the service sector, migration to the region has led to a tenfold increase in population since 1940, placing stress on water resources already fully committed during the early periods of mining and agriculture. There is, of course, a great deal of literature that analyses the possibility of increasing efficiency of existing water uses, especially through the establishment of market mechanisms for managing the liquid, improved technology and infrastructure, or the acquisition of new sources. This literature is aimed a creating solutions to specific problems, but often forgets some of the larger issues. The tradition of Mexican anthropology and history that these three authors work within - and have reshaped in important ways - has for a long time led the way on crucially important but often neglected issues of sustainability, power, and the long-term evolution of human-environment relationships. With little love for the walls that limit scientific inquiry, these articles engage in cross-border dialogue about the cross-border dynamics of cross-border waters.

\section{References}

Aboites Aguilar, L. 1998. El agua de la nacion: una historia politica de México (1888-1946). México: CIESAS. - 1995. Norte precario: poblamiento y colonización en México (1760-1940). México: Colmex.

- 1988. La irrigación revolucionaria: historia del sistema nacional de riego del Río Conchos, Chihuahua. 1927-1938. México: Secretaría de Educación Pública / CIESAS.

- 2012. The transnational dimensions of Mexican irrigation, 1900-1950. Journal of Political Ecology 19: 70-80.

Armillas, P. 1949. Notas sobre sistemas de cultivo en Mesoamerérica: cultivos de riego y humedad en la cuenca del Río de las Balsas. Anales del Instituto Nacional de Antropología e Historia 3: 85-113.

Donahue, J and B. R. Johnston. 1997. Water, culture and power: local struggles in global context. Washington DC: Island Press.

Evans, S. forthcoming. Damming Sonora: an environmental and transnational history of water, agriculture, and society in northwest Mexico. Tucson: University of Arizona Press.

Freeman, L.G. 1986. Pedro Armillas Garcia (1914-1984) American Anthropologist 88(3): 687-92.

González, A. 2007. Agua y agricultura : Ángel Palerm, la discusión con Karl Wittfogel sobre el modo asiático de producción y la construcción de un modelo para el estudio de Mesoamérica. Mexico: Universidad Iberoamericana / Agencia Española de Cooperación Internacional.

Greenberg, J. and T. K. Park. 1994. Political ecology. Journal of Political Ecology 1(1): 1-12.

Maganda C. 2012. Border water culture in theory and practice: political behavior on the Mexico-U.S. border. Journal of Political Ecology 19: 81-93.

Martínez Saldaña, T. 1980. El costo social de un éxito político: la politica expansionista del estado Mexicano en el agro lagunero. Texcoco, Mexico: Colegio de Posgraduados.

- 1999. La diaspora Tlaxcalteca. Tlaxcala: Gobierno del Estado de Tlaxcala.

- 2012. Water rituals on the Bravo/Grande River: a transnational political and ecological inheritance. Journal of Political Ecology 19: 57-69.

Martínez Saldaña, T. and J. Palerm Viqueira. 1997. Antología sobre pequeño riego. Texcoco, Mexico: Colegio de Posgraduados.

Melville, R. and S. Whiteford. 2002. Protecting a sacred gift: water and social change in Mexico. San Diego: Center for U.S.-Mexico Studies.

Mintz, S. 1979. The role of water in Steward's cultural ecology. Journal of the Steward Anthropological Society 11(1): 17-32.

Palerm, A. 1951. El regadío en Mesoamérica y la revolución urbana. B.A. thesis, Escuela Nacional de Antropología e Historia de México.

- 1952. La civilización urbana, Historia Mexicana II (2): 184-209.

- 1954. La distribución del regadío en el área de Mesoamérica, Ciencias sociales 5: 2-15, 64-74.

- 1955. The agricultural bases of urban civilization in Mesoamerica. In J. Steward, et al. (eds.) Irrigation civilizations: a comparative study. Washington: Pan American Union.

- 1980. Antropología y marxismo. Mexico: Nueva Imagen. 
Palerm, A. and E. Wolf. 1954. Irrigation in the old Alcohua domain, Mexico. Southwestern Journal of Anthropology 11: 265-81.

- 1957. Ecological potential and cultural development in Mesoamerica. Studies in human ecology. Social science monograph 3 ed. Washington DC: Pan American Union. Pp. 1-37.

Palerm, J. 1995. Sistemas hidráulicos y organización social. La polémica sobre el Acolhuacan septentrional. Mexican studies/estudios mexicanos 11(2): 163-178.

Palerm, J. and T. Martínez. 2000. Antología sobre pequeño riego, volumen II. Organizaciones Autogestivas. Texcoco, Mexico: Colegio de Posgrados, Plaza y Valdes.

Pisani, D. 2002. Water and American government: the Reclamation Bureau, national water policy, and the west: 1902-1935. Berkeley: University of California Press.

- 1984. From family farm to agribusiness: the irrigation crusade in California, 1850-1931. Berkeley: University of California Press.

Rivera, J. 2002. The acequia culture. Albuquerque: University of New Mexico Press.

Rodriguez, S. 2006. Acequia: water sharing, sanctity, and place. Santa Fe, NM: School of American Research Press.

Roseberry, W. 1978. Historical materialism and The People of Puerto Rico. Revista/review Interamericana 8(10): 26-36.

Sánchez Munguía, V. (ed.). 2005. El revestimiento del Canal Todo Americano. ¿Competencia o cooperación por el agua en la frontera México-Estados Unidos? Tijuana, Mexico: El Colegio de la Frontera Norte, Plaza y Valdés.

Scott, J. 1998. Seeing like a state: how certain schemes to improve the human condition have failed. New Haven: Yale University Press.

Steward, J.H. 1930. Irrigation without agriculture. Papers of the Michigan Academy of Science, Arts and Letters 12: $149-156$.

-1933. Ethnography of the Owens Valley Paiute. Publications in American archaeology and ethnology 33: 233-50.

- 1949. Cultural causality and law: a trial formulation of the development of early civilizations. American Anthropologist 51 (1): 1-27.

- (ed.) 1955. Irrigation civilization: a comparative study. Washington D.C.: Pan American Union.

Warman, A. 1975. Y venimos a contradecir: los campesinos de Morelos y el estado nacional. Mexico DF: CISINAH.

Wittfogel, K. 1938. Die theorie der orientalischen gesellschaft. Zeitschrift für Sozialforschung 7 (1 and 2). Paris: Alcan.

- 1957. Oriental despotism: a comparative study of total power. New Haven, CT: Yale University Press.

Worster, D. 1992. Rivers of empire: water, aridity and the growth of the American West. New York: Oxford University Press. 


\begin{abstract}
This article is an introduction to a special section of the Journal of Political Ecology that presents a Mexican perspective on the transnational dimensions of water use and management in the Mexico-U.S. borderlands. Three articles by leading Mexican scholars discuss the anthropology and history of water in the borderlands. The articles are interdisciplinary, and are linked in different ways to pioneering research on water in Mexico established by Angel Palerm.
\end{abstract}

